\title{
Clash over too demanding Euro-water standards
}

London. Complaints that European standards for drinking water are uneconomically over-stringent are mounting. In Britain, where water utilities in England and Wales have been privatized in the past two years, the head of the regulatory body that oversees the prices they now charge has warned that customers may not be willing to meet the costs resulting from legislation aimed at improving the quality of drinking water

The warning comes from Ian Byatt, director-general of the Office of Water Services (OFWAT), just as the European Commission in Brussels is preparing to negotiate

\section{IMAGE UNAVAILABLE FOR COPYRIGHT REASONS}

\begin{abstract}
Thames Water's Tony Rachwal with the fine carbon for the Thames Superfilter, promising "crystal clear drinking water."
\end{abstract}

a possible revision of the water quality standards set in 1975, which are now mandatory in all member states of the European Communities (EC).

Changes in current standards, particularly those specifying maximum levels of nitrates and pesticides, are being demanded by Europe's water industry on the grounds that they are too demanding and also "unscientific". The industry argues that the current nitrate limit of 50 micrograms per litre, for example, based almost entirely on the avoidance of infantile methaemoglobinaemia ("blue baby" disease), takes no account of its virtual disappearance where public supplies of water are treated.

Europe's water companies, organized through a trade association known as EUREAU, also want the limits on pesticide residues rewritten. These fix an upper limit of 0.1 micrograms per litre for individual pesticides, or 0.5 micrograms for all pesticides. Given the detection techniques of 1975 , these were then regarded as a "surrogate zero".

Backed by several EC members including Britain, the companies want new pesti- cide rules based on guidelines prepared by the World Health Organization. They specify limits based on observed toxicity of individual chemicals rather than sensitivity of detection techniques. In most cases, upper limits are 0.2 micrograms per litre.

But any move to relax water quality regulations will be fiercely resisted by environmental groups. Last week, Friends of the Earth $(\mathrm{FoE})$ in London claimed that delays in the introduction of the 1975 regulations in Britain meant that "at least 14.5 million" people are still drinking "sub-standard" water. At the prompting of the FoE, the EC environment commissioner has told Britain that it is not satisfied with its explanation for delay, and is considering referring the matter to the European Court of Justice.

The pressure groups also have support in Brussels for their claims that complaints of excessive regulation are motivated as much by concerns about the profitability of the water companies as about the effectiveness of the services provided to customers. Ioannis Paleokrassas, the EC environment commissioner, has already dismissed OFWAT's criticism of EC directives, arguing that the real failure has been Britain's reluctance to enforce the "polluter pays" principle on its farmers and waste-producing industries.

Even if the water industry manages, as seems likely, to persuade the European Commission to relax the rules on water quality, a political problem remains. Any proposed changes would need to be unanimously approved by all member states.

Thus the main thrust of OFWAT's advice to the British government is that it should seek to mitigate the impact of future regulations in the process of being drawn up, rather than to cut back on those already in force.

OFWAT warns that water bills are likely to increase five per cent faster than the expected rate of inflation between 1995 and 2000 , with some customers facing an increase of up to $£ 100$ on bills that which now average $£ 100$ a year.

Even if the EC does agree to change the most heavily criticized standards, such as those for nitrates and pesticide residues, new regulations are unlikely to be in force quickly enough to affect the short-term investment plans of the water companies.

Thames Water Utilities Ltd, for example, suppliers of most of London's water, is already committed to spending $£ 380$ million over the next three years to reduce pesticide residues to the existing EC limits. "We are all lined up to meet the standards being required of us; its just that we don't want any more like that", says a company spokesman.

\section{SSC supporters hope for a last-ditch reprieve}

Washington. Supporters of the Superconducting Super Collider (SSC) are asking the US administration to pledge support for a future particle accelerator in East Asia in exchange for support now to save the troubled Texan project.

The House of Representatives last month voted down funding for the project (see Nature 364, 6; 1993), but its supporters think it could yet be saved by agreement between the House and the Senate. With this in mind, George Brown (Democrat, California), chairman of the House Science, Space and Technology Committee, wants the administration to promise Japan and other Asian nations three things in return for some financial support - a "full voice" in project management, an allotted share of science time and a pledge to help build the nextgeneration particle collider in Asia.

"Now is the time to establish a fully international framework for high-energy physics", says Brown, who wants to see Europe, the United States and Asian countries join in such a framework in time to save the SSC. "Obviously this will look like a desperate plan to keep the Super Collider alive...but in my own defence ... I've always said the SSC should operate this way."

Brown says such a framework would involve no exchange of money between Europe and the United States, but a commitment from both groups that the world's next great accelerator would be built in East Asia, in exchange for financial support now. The only possible source of funds sufficient to save the SSC is Japan, but the new framework might also interest Hong Kong, South Korea, Taiwan, Australia and some smaller countries.

"A commitment from them, backed up with a small amount of money this year" would suffice to get the new arrangement off the ground, Brown says. He has discussed his plan with John Gibbons, President Clinton's science adviser, but received only a vague assurance that it was worthy of further exploration.

But Japanese officials are sceptical, and question the ability of the US administration to deliver a long-term promise, given congressional constraints. "Certainly if other countries promise to build the next collider in Japan, it helps us to contribute to the SSC", says Akihiro Maki of the Japanese Society for the Promotion of Science Washington office, but he doubted whether "any US administration can make such a promise"

The Japanese say that if Clinton is serious about saving the $\mathrm{SSC}$, he should make his own commitment to it clear, and make a formal request for support to their government.

Colin Macilwain 